\title{
IMPROVING THE EFFICIENCY OF FOREIGN LANGUAGE TEACHING FOR FUTURE NON-LINGUISTIC SPECIALISTS WITH THE APPLICATION OF THE SIOP MODEL
}

\section{ПІДВИЩЕННЯ ЕФЕКТИВНОСТІ НАВЧАННЯ ІНОЗЕМНИХ МОВ МАЙБУТНІХ ФАХІВЦІВ НЕМОВНИХ СПЕЦІАЛЬНОСТЕЙ ІЗ ЗАСТОСУВАННЯМ МОДЕЛІ SIOР}

\author{
Maria Rakovs' ka' \\ Dariya Pustovoichenko
}

DOI: https://doi.org/10.30525/978-9934-26-069-8-10

Abstract. Introduction. The article deals with the problem of students' academic professional literacy development by means of a foreign language based on the implementation of the SIOP Model. The foundations of the question have been borrowed from the SIOP (Sheltered Instruction Observation Protocol) Model that focuses on helping English Language Learners (ELLs) with academics in a mainstream classroom. The SIOP Model provides a practical and flexible tool for educators to use in planning, implementing and observing Sheltered Instruction. The SIOP Model is one of the two major areas, the other being General English, which is established in the English-speaking world. The professionally oriented English course is developed for students from different non-linguistic specialties. The goals, objectives, content of the course are compiled according the students' requirements of real target foreign language communication situations. The principles and approaches that underlie occupational mobility are outlined. It is revealed that occupational mobility serves as a criterion for evaluating the effectiveness of professional development.

The aim of the study. The aim of this paper is to outline the improving the efficiency of foreign language teaching for future non-linguistic specialists with the iplementation of the SIOP Model.

\footnotetext{
${ }^{1} \mathrm{PhD}$ in Pedagogy, Associate Professor at the Department of General and Applied Linguistics, V.O. Sukhomlynskyi Mykolaiv National University, Ukraine ${ }^{2}$ Lecturer at the Department of General and Applied Linguistics, V.O. Sukhomlynskyi Mykolaiv National University, Ukraine 
Methods of the research. Methods of the research include theoretical - study of literature, experience on the problem, theoretical analysis of philosophical, sociological, psychological, pedagogical literature on research topics, synthesis of theoretical and empirical material, its generalization and systematization of data, modeling, comparison, forecasting; as well as a set of empirical methods - observations, study and generalization of pedagogical experience.

Results. It is revealed that The SIOP Model was developed to assist mainstream teachers in using research-based practices which ensure ELLs success with academic language and vocabulary. Over time, the model has proven to be a form of best practices for educators. It is also known to reach ELLs by focusing on academic language in order to obtain optimal results. Learning foreign languages in the context of intercultural paradigm has great potential for personal development. It is determined that professional mobility and competence are interdependent. The curriculum should include a cultural component, on the basis of which intercultural communication competence is formed. It is revealed that in the process of forming professional mobility it is very important to distinguish personal characteristics that provide mobility, activity and creativity of a person. The pedagogical conditions of professional mobility with the help of foreign languages are outlined. It is determined that the process of learning foreign languages is aimed at forming elements of general cultural and professional competences. Good command of a foreign language enables future professionals to effectively carry out their professional activities in their field, which will significantly increase the level of language training. It is considered that the formation of communication skills at the present stage implies the development of students' communicative competence. The component of directions of formation of multicultural communicative competence in the conditions of studying foreign languages for professional purposes is considered.

Conclusion. The purpose of teaching foreign languages for future nonlinguistic specialists with the application of the SIOP Model should upgrade the skills and abilities that allow the future specialist to effectively pursue a professional activity in their field: work with foreign literature, participate in discussions in a foreign language, speak or write a professional translation of business literature in professional field. The process of foreign languages 
learning with the implementation of SIOP Model is aimed at forming professional competencies. The combination of these competencies in the future will determine the level of training future professionals, the degree of their readiness for professional self-determination and professional activity. The SIOP components and functions demonstrate a number of aspects that make a teacher's performance effective. The SIOP Model combines the features of effective learning into one whole, integrates a foreign language with professional learning that in the context of modern Ukrainian education is especially relevant in the transition to a system of training future specialists.

\section{1. Ветуп}

Інтеграція українського суспільства до міжнародного соціально-економічного, інформаційного, культурного простору зумовлює потребу в ефективній дидактичній технології, що забезпечувала б неперервну взаємодію співучасників навчання, умотивоване залучення їх до навчально-виховного процесу. Інтенсифікація міжкультурного діалогу, прискорення темпів науково-технічного прогресу, активізація міжнародних контактів та обмінів у різних сферах, вдосконалення нових технологій на новому етапі розвитку полікультурного суспільства вимагають наявності професійно мобільних фахівців, орієнтованих на суміжні галузі професійної діяльності.

Вивчення іноземної мови сьогодні-це не лише процес становлення особистості, а й спосіб розвитку професійного мислення майбутнього фахівця, сфера розвитку його практичних навичок. Знання іноземної мови на професійному рівні фахівцями різних галузей стає глобальним викликом для України. Досі існують труднощі у навчанні різноманітних студентів 3 лінгвістичної та культурної точки зору. Щоб студенти мали успіх у майбутньому та стали продуктивними громадянами, вони повинні отримати кращі освітні можливості.

Працюючи зі студентами немовних спеціальностей з різним рівнем базової підготовки іноземних мов, викладачі змушені шукати шляхи досягнення успіху студентів, створювати стратегії викладання іноземних мов для студентів з обмеженими знаннями i, водночас, навчати студентів, які вже добре володіють іноземною мовою і прагнуть вдосконалення. Для вирішення цих проблем мають відбутися фундамен- 
тальні зміни у розвитку підготовки викладачів, розробці навчальних програм, навчальних матеріалів та оцінювання.

На думку Л. Сушенкової. проблема професійної мобільності постала перед людиною у зв'язку з необхідністю пристосовуватись до нових умов діяльності, пов'язаних з процесами диференціації та інтеграції у професійній діяльності [8, с. 11]. В системі професійної освіти в становленні навчальної мотивації найважливішу роль відіграють пізнавальні інтереси і мотиви професійної діяльності. Оскільки іншомовна компетентність трактується в контексті професіоналізму, то доцільно розглядати питання формування мотиваційної основи розвитку компетентності в області іноземних мов з точки зору ролі професійної мотивації у формуванні мотивації навчання.

Знання іноземної мови дозволяє майбутньому спеціалісту ефективно займатися професійною діяльністю у своїй галузі: працювати 3 іноземною літературою, писати доповідь чи звіт, писати статтю, брати участь у дискусіях іноземною мовою, виконувати усний або письмовий переклад літератури у професійному напрямку. Це значно підвищить рівень мовної підготовки майбутнього фахівця.

Модель професійного розвитку викладача іноземних мов, або протокол ефективності роботи викладача (SIOP) спрямована на застосування методів викладання іноземних мов, які роблять зміст предмету зрозумілим для тих, хто вивчає англійську мову. Компоненти та функції SIOP демонструють ряд аспектів, які роблять діяльність викладача ефективною. Модель SIOP об'єднує особливості ефективного навчання в одне ціле, інтегрує іноземну мову з навчанням професійної діяльності, що в контексті сучасної української освіти особливо актуально при переході до системи підготовки фахівців.

\section{2. Огляд структури моделі SIOP}

Модель професійного розвитку викладача іноземних мов, або протокол ефективності роботи викладача (SIOP) був розроблений вченими Echevarria, Vogt та Short. Модель SIOP спрямовує викладачів іноземних мов на створення стратегій моделювання змісту предмету, які мають вплив на покращення вмінь та навичок володіння іноземною мовою. Модель пройшла тестування у закладах вищої освіти США та країнах Європи, та довела свою ефективність у навчанні лінгвістично та куль- 
турно різноманітних студентів. Компоненти моделі SIOP включають підготовку до заняття, побудову передумов, способи адаптації інформації для студентів, стратегії взаємодії, тактики проведення занять, оцінку розуміння матеріалу студентами та ефективності викладача.

Імплементація та розробка технологій моделі SIOP сприятиме формуванню та розвитку у студентів немовних спеціальностей навичок професійного спілкування, вміння будувати комунікацію при груповому вирішенні проблеми, здатність проектувати нові форми дії, а також здатність використовувати іноземну мову для отримання нових знань у професійній сфері та вирішення професійних завдань.

Модель SIOP складається з 30 показників, згрупованих за вісьмома основними. компонентами:

- елементи в рамках підготовки занять (процес планування заняття (зміст і мовні цілі, додаткові матеріали), створення значущих видів діяльності;

- створення передумов (встановлення зв'язку зі студентами, спираючись на їх досвід попереднього навчання, а також розвитку їх академічного словника;

- зрозуміла подача інформації (викладачі повинні коригувати свою промову, моделювати академічні завдання і використовувати мультимодальні методи для поліпшення розуміння);

- компонент «Стратегії» (використання скаффолдінгу і розвиток навичок мислення більш високого рівня;

- взаємодія (спонукає викладачів заохочувати студентів до вдосконалення власного мовлення та розподілу студентів відповідно до мовного розвитку;

- практика і застосування (імплементація по практиці і розширенню змістовного навчання);

- проведення заняття з використанням навчальних матеріалів дозволяє презентувати викладачам заняття, які відповідають запланованим цілям та сприяють залученню студентів;

- компонент огляду та оцінки дозволяє викладачам переглянути ключові мовні та змістові поняття, оцінити навчання студентів та надати конкретні академічні відгуки щодо результатів [12, с. 16].

Розвиток академічної професійної грамотності студентів засобами іноземної мови на основі імплементації моделі професійного розвитку 
викладача (SIOP) дасть змогу ефективно підготувати студентів до професійної діяльності в сучасному світі.

\section{3. Цілі, принципи та завдання під час реалізації моделі}

У рамках проведеного дослідження з'ясувалося, що у студентів немовних спеціальностей існує ряд ситуацій академічного спілкування, пов'язаних з поточною навчальною діяльністю студентів в рамках досліджуваної спеціальності, в яких наявність у студентів певного рівня сформованості відповідних англомовних мовленнєвих навичок і вмінь сприяло б підвищенню ефективності зазначеної діяльності.

Цілі курсу проектуються із цільових ситуацій, в яких студенти повинні навчитися здійснювати іншомовне спілкування. Після закінчення курсу академічного навчання іноземної мови студенти повинні вміти:

1) ефективно користуватися англомовною літературою за фахом, що представляється необхідним, коли зміст чи обсяг літератури, наявної на рідній мові, не дозволяють вирішувати завдання, які виникають у ході здійснення навчальної діяльності;

2) адекватно здійснювати іншомовне спілкування в рамках міжнародних студентських наукових семінарів та конференцій;

3) писати наукові статті та тези, есе відповідно до вимог стилю, прийнятого в англомовному науковому світі;

4) розуміти зміст лекцій, що читаються англійською мовою.

Так, використання англомовної літератури по спеціальності в процесі здійснення навчальної діяльності студентами припускає читання та критичну інтерпретацію складних з погляду структури та змісту насичених аргументацією текстів.

5) пошук інформації, що відповідає заданим вимогам;

6) використання довідкової літератури зі спеціальності та мови, яка вивчається.

Предметно-тематичний зміст курсу повинен базуватися на матеріалі, вже вивченому студентами в рамках дисциплін, пов'язаних 3 основною спеціальністю та служити для студентів додатковим стимулом внутрішньої мотивації для вивчення спеціальності загалом і курсу іноземної мови зокрема.

Під час впровадження моделі професійного розвитку викладача (SIOP) ми повинні дотримуватися наступних принципів навчання: 
- впровадження програмного матеріалу, що сприяє професійному i суспільному становленню;

- сприяння постійному прагненню студентів до самовдосконалення, самоосвіти, підвищенню інтелектуального потенціалу і компетентності;

Основні завдання під час реалізації програми такі:

- формування у студентів загальних навчальних компетенцій (декларативні знання, вміння й навички), розвиток здібностей до самооцінки та самостійного навчання, що дасть змогу студентам продовжувати навчання в академічному і професійному середовищі як під час навчання у закладах вищої освіти, так і після отримання диплома про вищу освіту;

- сприяння становленню критичного самоусвідомлення та вмінь спілкуватися, робити вагомий внесок у міжнародне середовище, що постійно змінюється;

- формування готовності до конкуренції на ринку праці, досягнення певного соціально-професійного статусу;

- стимуляція розвитку та розкриття творчих здібностей студентів як запорука успішної інтелектуальної діяльності;

- допомога в усвідомленні життєвих цілей, визначенні професійних намірів, бажання самовдосконалення, самоосвіти;

- забезпечення широкого розуміння важливих і різнопланових міжнародних соціокультурних проблем;

- формування у студентів загальних та професійно орієнтованих комунікативних мовленнєвих компетенцій для забезпечення їхнього ефективного спілкування в академічному і професійному середовищі.

\section{4. Формування професійних компетенцій майбутніх фахівців}

Процес вивчення дисципліни іноземною мовою спрямований на формування елементів загальної та професійної компетенції. Саме сума цих компетенцій у майбутньому визначатиме рівень професійної підготовки майбутніх фахівців, ступінь їхньої готовності до професійного самовизначення та професійної діяльності.

Соціалізація в процесі професійної підготовки є важливою формою соціального регулювання процесу становлення майбутнього професійно мобільного фахівця. Формування компетентностей можливе 
лише за допомогою відповідного досвіду та спілкування. Впровадження та розвиток модельних технологій сприятиме формуванню та розвитку у студентів немовних спеціальностей професійних комунікативних навичок, вміння будувати спілкування при груповому вирішенні проблем, вміння розробляти нові форми дій та вміння використовувати іноземні мови для отримання нових знань та вирішення професійних проблем. Це передбачає розширення кола можливих ситуацій іншомовної комунікативної поведінки, ефективність якої буде залежати від успіху професійної діяльності майбутнього фахівця.

О. Язловецька вважає, що необхідно створити оптимальні умови для розвитку особистості студента, надати йому допомогу і підтримку в самовихованні, самовизначенні, моральному самовдосконаленні, засвоєнні соціального досвіду. Одним із чинників, який впливає процес соціалізації у цьому віці, $є$ навчальна діяльність. Ефективна соціалізація передбачає успішну адаптацію в суспільстві, а також здатність особистості в певній мірі протистояти тим соціальним колізіям, які заважають iii саморозвитку, самореалізації та самоствердженню [10, с. 263].

Професіоналізм майбутнього фахівця освіти виявляється в готовності до поетапного здійснення його соціалізації на основі збереження суб'єктності шляхом спілкування, діяльності та управління. Наприкінці XX сторіччя актуалізується проблема осмислення соціалізації особистості майбутнього фахівця з педагогічних позицій, окремі аспекти соціалізації розглядаються вченими-педагогами, котрі в курсі загальної педагогіки відносять це поняття до основних, а феномен соціалізації виступає іiі методологічним інструментом [6].

Серед вимог, що висуваються сьогодні до професійно мобільного кваліфікованого фахівця, Л. Амірова виокремлює такі:

- особистісна компетентність - сукупність компетенцій, що стосуються особистості (набір характерних якостей окремої особистості): ініціативність, впевненість у собі, здатність до творчості, здатність пристосовуватися до середовища, що змінюється, готовність до ризику та ін.;

- професійна компетентність - сукупність компетенцій людини, що стосуються ï професії (здатність до виконання роботи): знання, уміння і досвід, якими вона володіє у своїй професії;

- соціальна компетентність - сукупність компетенцій людини, що стосуються іiї соціального життя (вміння жити і працювати в соціумі, 
комунікабельність, здатність вживатися, працювати з іншими людьми, здатність переборювати конфлікти, здатність до самоорганізаціі), постановка і досягнення цілей, прийняття рішень та ін.;

- особливі переваги особистості, USP особистості - характерні риси, переваги особистості, які роблять людину унікальною і можуть бути корисні, цікаві, наприклад, роботодавцю [1].

Сьогодні все більше уваги приділяється вивченню іноземних мов, $\mathrm{i}$ це стосується всіх сфер життя, де іноземні мови є запорукою розвитку міжнародних відносин, культурного обміну між представниками різних країн. Мультикультуралізм та знання іноземних мов вважається необхідним для освіченої людини.

Очевидним позитивним результатом процесу глобалізації стала можливість спілкуватися з людьми з різних культур. Інтеграція українського суспільства у міжнародний соціально-економічний, інформаційний та культурний простір вимагає ефективної дидактичної технології, яка забезпечувала б постійну взаємодію учасників.

Спеціаліст університету - це добре освічена людина 3 фундаментальною підготовкою. Відповідно, спеціаліст зі знаннями іноземної мови - інструмент виробництва та частина культури. Дуже важливо створити реальне середовище спілкування на практичних заняттях 3 іноземної мови, активно використовувати іноземні мови в побутових ситуаціях і за професійним спрямуванням.

Модель SIOP надає викладачам чітко сформульовану практичну модель навчання та визначається зарубіжними науковцями як найкраща основа практики викладання іноземної мови. Об'єднує особливості ефективного навчання в одне ціле, інтегрує іноземну мову 3 навчанням професійної діяльності. Вона спрямовує викладача на розуміння, що успішний та послідовний професійний розвиток повинен включати перспективи для усіх зацікавлених сторін.

Основною метою навчання іноземних мов у закладах вищої освіти стає формування та розвиток умінь і навичок іншомовного спілкування, що передбачає досягнення студентами такого рівня комунікативної компетенції, який був би достатнім для здійснення спілкування в певних комунікативних сферах.

Головним у вивченні іноземних мов в університетах $є$ формування та розвиток комунікативних навичок іноземною мовою, що передба- 
чає досягнення рівня комунікативної компетентності, достатнього для спілкування в певних сферах спілкування.

Провідними викликами сучасного соціуму є підготовка професійно мобільного фахівця, який досконало володіє культурою й педагогічними технологіями, ефективно використовує існуючі засоби комунікації. Незаперечно важливою є потреба у формуванні професійної мобільності саме у майбутніх фахівців, оскільки у сучасних умовах важливо не лише мати професію, а й бути готовими змінити іiї протягом життя.

Існують різні методи вивчення іноземних мов. Кожному методу притаманні позитивні та негативні сторони і за певних умов мають свою об' єктивну цінність.

Основним завданням інтенсивних методів є вивчення великої кількості слів за короткий час за допомогою рольових ігор та інших засобів. Цей метод навчає грамотно висловлювати свої думки, щоб співрозмовник міг вас зрозуміти. Традиційний спосіб дає можливість опанувати граматику, навчитися читати, писати, мати багатий словниковий запас. На думку Є. Пасова, комунікативний метод орієнтований на організацію навчального процесу, адекватний процес реального спілкування через моделювання основних законів мовленнєвого спілкування [4]. За визначенням Мішеля Буарона, комунікативний метод є основним у вивченні іноземної мови, який направлений на доцільні теми, справжні ситуації та задачи, корисні завдання. Він виділяє наступні складові та компетенції:

а) лінгвістична компетенція: ознайомлення 3 елементами словника та майстерність певних синтаксичних правил, завдяки яким ці елементи поєднуються настільки, щоб породжувати значущі висловлювання;

б) соціолінгвістична компетенщія: можливість використовувати та інтерпретувати лінгвістичні елементи, які використовуються в функції комунікативної ситуації (це контекст, який надає інформацію з ким, 3 якою метою, де обумовлює вибір лінгвістичних елементів);

в) дискурсивна компетенція: можливість сприйняття та підтвердження зв'язку чітких завдань в комунікативному обміні;

г) стратегічна компетенція: можливість звертання до стратегій комунікації, вербальних або не вербальних; 
д) соціокультурна компетенція: певна фамільярність з соціокультурним контекстом, в якому використовується мова;

є) соиіальна компетенція: свобода обирати вільний шлях взаємодії 3 іншими, та впевненість у собі, яка передбачає схильність до емпатії та спритність в питанні соціальних стосунків [11, с. 5].

Важливим моментом $є$ той факт, що в процесі навчання студенти поглинають в культуру, історію тієї країни, мову якої вивчають. Таким чином просте спілкування знімає психологічний страх і хвилювання та студенти починають грамотно й зрозуміло висловлювати свої думки. Тому дана методика стала дуже популярною завдяки своєї ефективності і набула більшого поширення, основними принципами якого виступає спрямованість на досягнення соціальної взаємодії при наявності віри викладача в успіх своїх учнів. Наявність даного метода свідчить про зростаючий інтерес до навчання іноземних мов і прагнення викладачів переосмислити їх роль та місце у світі.

Спілкування - це соціально зумовлений процес обміну різною природою та змістом інформацією, який цілеспрямовано передається різними засобами та з метою досягнення взаєморозуміння між партнерами відповідно до встановлених норм та правил. Вивчення іноземних мов та їх використання як засобу міжнародного спілкування сьогодні неможливе без глибоких та різноманітних знань носіїв цих мов, їх менталітету, національного характеру, звичаїв, традицій тощо. Тільки поєднання цих двох типів знань - мови та культури - забезпечує ефективне та продуктивне спілкування [2].

Однією з найважливіших сфер людської діяльності є професійна діяльність. I в контексті сучасної української освіти це особливо актуально при переході до системи навчання. С. Ступіна зазначає, що сучасна спрямованість освіти на формування компетентностей як готовність і здатність людини працювати та спілкуватися передбачає створення дидактичних та психологічних умов, в яких учасник навчального процесу може виявляти не лише інтелектуальну та пізнавальну активність, а й особисте соціальне становище. Одним із сучасних напрямків «активного навчання» $є$ інтерактивне навчання. Інтерактивне навчання передбачає відмінну від звичної логіку освітнього процесу, не від теорії до практики, а від формування нового досвіду до його теоретичного осмислення через застосування. Інтерактивна 
модель навчання найефективніша в додатковій професійній освіті, неформальній освіті дорослих, оскільки дорослі мають великий життєвий і професійний досвід [7, с. 17].

Формування компетентностей можливе лише за допомогою відповідного досвіду та спілкування, і такий досвід можна отримати в режимі інтерактивного навчання. В системі професійної освіти в становленні навчальної мотивації найважливішу роль відіграють пізнавальні інтереси і мотиви професійної діяльності. Оскільки іншомовна компетентність трактується в контексті професіоналізму, то доцільно розглядати питання формування мотиваційної основи розвитку компетентності в області іноземних мов з точки зору ролі професійної мотивації у формуванні мотивації навчання.

Професійні мотиви мають домінуючий вплив на ставлення до навчальних дисциплін. Студенти, які мають сильні професійні мотиви навчання, оцінюють важливість предметів та інтерес до них набагато вище, ніж ті, хто не прагне стати хорошим спеціалістом та набути необхідних поглиблених знань. Професійна підготовка може вважатися ефективною особливо тоді, коли професійно мобільний кваліфікований працівник вміє застосовувати професійні знання і знання іноземних мов одночасно.

При розгляді процесу формування та розвитку професіоналізму використовуються два поняття: компетентність та компетенція. Компетентність та компетенція є взаємодоповнюючими та взаємозалежними поняттями: компетентна особа, яка не має компетенції, не може повною мірою і в соціально значущих аспектах іiі реалізувати. Процес вивчення дисципліни з іноземної мови спрямований на формування елементів загальнокультурних та професійних компетентностей. Саме поєднання цих компетенцій надалі визначатиме рівень підготовки майбутніх фахівців, ступінь їх готовності до професійного самовизначення та професійної діяльності. Професійні компетенції, що становлять фундамент професійної компетентності, $є$ фактором формування професійної мобільності, а професійна мобільність сприяє формуванню професійної компетентності.

На думку М. Вятютнєва, комунікативна компетентність визначається як вибір та реалізація програм створеної програми поведінки залежно від здатності людини орієнтуватися в ситуаціях спілкування 
та змісту класифікувати ситуації за темою, завданнями та комунікативними напрямами [3, с. 38].

Вивчення іноземних мов та їх використання як засобу міжнародного спілкування сьогодні неможливо без глибокого і різнобічного знання культури носіїв цих мов. Володіння іноземними мовами сприяє процесу розширення світогляду особистості студента, активізації культурного освоєння світу, розуміння інших соціумів та народів, що сприяє комунікації культур і професійному зростанню та вдосконаленню знань студентів. Вивчення іноземних мов та їх використання як засобу міжнародного спілкування сьогодні неможливо без глибокого і різнобічного знання культури носіїв цих мов, їхнього менталітету, національного характеру, способу життя, бачення світу, звичаїв, традицій тощо. Тільки поєднання цих двох видів знання - мови і культури - забезпечує ефективне та плідне спілкування» [9, с. 95].

Володіння іноземною мовою дозволяє майбутньому фахівцю ефективно здійснювати професійну діяльність у своїй сфері: працювати 3 зарубіжною літературою, виступати з доповіддю або повідомленням, брати участь в дискусії іноземною мовою, виконувати усний або письмовий переклад літератури за професійним спрямуванням. Це значно підвищить рівень мовної підготовки майбутнього фахівця. Робота студентів в рамках окресленої дисципліни дозволяє їм краще сприймати інформацію із зарубіжних джерел, розуміти теоретичні та методологічні положення і принципи зарубіжної психології і звісно сприяє професійному зростанню і вдосконаленню знань студентів. Одним з етапів формування міжкультурної компетенції мають стати тренувальні вправи комунікативного та дослідницького характеру.

У навчально-виховному процесі доцільно враховувати такі рекомендації при навчанні іноземної мови майбутнім фахівцям немовних вузів: 1) обгрунтовувати професійне значення компетентності з іноземної мови; 2) створити сприятливу атмосферу на практичних заняттях, що забезпечить успішність спілкування іноземною мовою студентами; 3) організовувати навчально-практичну діяльність студентів, а саме: участь у наукових конференціях, семінарах, тренінгах із фахівцями в профільній галузі, в ході яких студенти можуть продемонструвати свої знання та навички іншомовного спілкування. 
Інтерактивна модель навчання відображає постійну взаємодію викладача зі студентами і студентів з одногрупниками. Відбувається спілкування всіх учасників колективу. Для вирішення навчальних завдань викладач за даною моделлю навчання використовує такі інтерактивні форми: дебати, ділові та рольові ігри, навчальні групові дискусії, мозковий штурм, круглий стіл, фронтальне опитування, фокусгрупи, тренінги; аналіз конкретних, практичних ситуацій. Добре володіння іноземною мовою дозволяє майбутнім фахівцям ефективно здійснювати свою професійну діяльність у своїй галузі, що значно підвищить рівень мовної підготовки.

Факторами компетентності майбутніх фахівців є якісна освіта, життєвий досвід, вміння застосовувати знання на практиці.

\section{5. Інтерактивне навчання як одна із складових моделі SIOP}

Інтерактивне навчання дозволяє вирішувати одночасно кілька завдань, головною з яких є розвиток комунікативних умінь і навичок. Це допомагає встановленню емоційних контактів між студентами, формується вміння працювати в команді, прислухатися до думки своїх товаришів, що розвиває толерантність, забезпечує високу мотивацію, міцність знань, творчість і фантазію, комунікабельність, активну життєву позицію, цінність індивідуальності, свободу самовираження, акцент на діяльність, взаємоповагу і демократичність. Також до переваг даної моделі навчання можна віднести наступні складові:

- розширення пізнавальних можливостей студентів;

- високий рівень засвоєння знань;

- партнерство між викладачем і студентами та зокрема всередині студентського колективу;

Творчі майстерні, майстер-класи, «круглі столи», дискусії, проектні семінари, кейс-технології, розбір ділової документації, рольові та ділові ігри, що імітують професійні ситуації, сприяють виробленню нових поглядів, формуванню умінь і навичок, моделювання свого нового досвіду, корекції негативних установок.

Основними складовими інтерактивних занять $є$ вправи і завдання, які виконуються студентами. Важлива відмінність інтерактивних вправ і завдань від традиційних в тому, що виконуючи їх, майбутні фахівці не стільки закріплюють раніше вивчений матеріал, скільки вивчають 
новий. Таким чином, організовуючи навчальний процес, який спирається на використанні інтерактивних методів навчання, треба заохочувати до процесу пізнання всіх студентів групи.

Сьогодні значна увага приділяється методам інтерактивного навчання із застосуванням комп'ютерних програм, що реалізують діяльнісний підхід до навчання. Засобами реалізації такого підходу слугують комплекси програмно апаратних засобів (комп'ютер, мультимедійний проектор, сенсорна дошка, графічний планшет тощо), за допомогою яких здійснюється навчально-пізнавальна діяльність студентів у закладах вищої освіти. Дуже ефективним є новий технічний засіб з використанням інформаційних технологій - це інтерактивні дошки, які в майбутньому можуть поступово витіснити традиційні дошки.

Важливими факторами компетентності людини виступають отримана нею якісна освіта, накопичений життєвий досвід, вміння професійно застосовувати знання на практиці. Інтерактивне навчання сприяє активізації навчально-пізнавального процесу, формуванню глибокої внутрішньої мотивації, надає можливості для інтелектуального та творчого розвитку, вияву ініціативи, розвиває комунікативні вміння. Тому використання саме цього виду навчання $є$ невід’ $€$ мною частиною процесу професійної підготовки майбутніх фахівців.

Сучасний фахівець має бути готовим діяти в умовах високої динаміки ринку праці. Для цього йому необхідно вміти працювати 3 іншомовними інформаційними потоками, бути динамічним, здатним аналізувати процеси, що відбуваються в оточуючому середовищі, бути гнучким та поліфункціональним.

Інтенсифікація міжкультурного діалогу, прискорення темпів науково-технічного прогресу, активізація міжнародних контактів та обмінів у різних сферах, вдосконалення нових технологій на новому етапі розвитку полікультурного суспільства вимагають наявності професійно мобільних фахівців, орієнтованих на суміжні галузі професійної діяльності.

Комунікація - це соціально обумовлений процес обміну інформацією різного характеру та змісту, переданої цілеспрямовано за допомогою різних засобів і має своєю метою досягнення взаєморозуміння між партнерами відповідно до визначених правил і норм.

Вивчення іноземних мов сьогодні неможливо без глибокого і різнобічного знання культури носіїв цих мов, національного характеру, мен- 
талітету, способу життя, звичаїв, тощо. Тільки поєднання цих двох видів знання - мови і культури - забезпечує ефективне та плідне спілкування [9].

Модель SIOP об'єднує особливості ефективного навчання в одне ціле, інтегрує іноземну мову з навчанням професійної діяльності. Домінуючий вплив на ставлення до навчальних дисциплін надають професійні мотиви. Студенти, які мають яскраво виражені професійні мотиви навчальної діяльності, оцінюють важливість предметів і інтерес до них значно вище, ніж ті, хто не прагне стати справжнім фахівцем, і отримати глибокі знання. Процес вивчення іноземної мови націлений на формування елементів загальнокультурних і професійних компетенцій. Саме сукупність даних компетенцій в майбутньому визначатиме рівень професійної підготовки майбутніх фахівців, ступень їх готовності до професійної самовизначеності та професійної діяльності.

\section{6. Фактори формування професійної мобільності майбутніх фахівців}

Професійна підготовка може вважатися ефективною лише тоді, коли результатом ï буде професійно мобільний кваліфікований працівник, який не тільки володіє спеціальними знаннями, а й вміє застосовуючи професійні знання і знання іноземних мов, приймаючи на себе відповідальність за власну діяльність. Головною метою діяльності будь-якого вищого навчального закладу є створення умов для підготовки професійного фахівця у своєї галузі.

Професійна мобільність і компетентність взаємозалежні. Професійні компетенції, що становлять фундамент професійної компетентності, $є$ фактором формування професійної мобільності. У найзагальнішому вигляді професійна мобільність характеризує готовність і здатність працівника до соціально-психологічних і функціонально-статусних змін, а точніше - до інноваційних перетворень себе і навколишнього соціуму. Очевидно, що розвиток цієї якості у майбутніх фахівців є одним із найважливіших завдань професійної школи. Вирішення цього завдання можливе за умови його сформованості у самих педагогів.

На думку I. Пашковської, професійна активність соціальна за своєю суттю, окрім того, протікає в рамках соціальної системи. Тож, мета та форми прояву професійної активності породжені суспільством і соціальним середовищем, в якому формується особистість. Тому можна 
стверджувати, що й професійна мобільність за своєю природою соціальна, адже вона існує тільки в соціальних системах, а іiі успіх залежить від соціального, освітнього середовища, у якому відбувається становлення особистості фахівця [5].

Поняттю «професійна мобільність» властива категорія адаптації, а саме готовність до професійної діяльності, оволодіння іiі змістом і формою на рівні, достатньому для самостійної роботи, готовність до прийняття системи цінностей, характерних для даного прошарку суспільства. Для успішного формування професійної мобільності необхідно виділити особистісні характеристики, що забезпечують мобільність людини.

Метою викладання іноземної мови для майбутніх фахівців із використанням моделі SIOP має бути актуалізація навичок і вмінь, що дозволяють майбутньому спеціалісту ефективно здійснювати професійну діяльність у своїй сфері. Навчаючи студентів з різними рівнями базової мовної підготовки, викладачі змушені самостійно створювати стратегії викладання іноземної мови для студентів з обмеженими знаннями i, водночас, навчати студентів, які вже добре володіють іноземною мовою та прагнуть їі вдосконалення. Розвиток академічної професійної грамотності студентів засобами іноземної мови із застосуванням моделі професійного розвитку викладача (SIOP) дасть змогу ефективно підготувати студентів до професійної діяльності в сучасному світі.

\section{7. Висновки}

Процес вивчення іноземних мов націлений на формування елементів загальнокультурних і професійних компетенцій. Саме сукупність даних компетенцій в майбутньому визначатиме рівень професійної підготовки майбутніх фахівців, ступень їх готовності до професійної самовизначеності та професійної діяльності.

Вузівський фахівець - це широко освічена людина, що має фундаментальну підготовку. Відповідно, іноземна мова фахівця такого роду знаряддя виробництва і частина культури. Рівень знання іноземної мови студентом визначається не тільки безпосереднім контактом 3 викладачем. Дуже важливо на заняттях з іноземної мови створювати комунікативні ситуації реального спілкування.

Володіння іноземними мовами сприяє процесу розширення світогляду особистості майбутнього фахівця, професійному зростанню та вдо- 
сконаленню знань. Знання іноземної мови на професійному рівні фахівцями різних галузей стає глобальним викликом для України. Досі існують труднощі у навчанні різноманітних студентів з лінгвістичної та культурної точки зору. Щоб студенти мали успіх у майбутньому та стали продуктивними громадянами, вони повинні отримати кращі освітні можливості.

Працюючи зі студентами з різним рівнем базової підготовки іноземних мов, викладачі змушені шукати шляхи досягнення успіху студентів, створювати стратегії викладання іноземних мов для студентів з обмеженими знаннями i, водночас, навчати студентів, які вже добре володіють іноземною мовою і прагнуть вдосконалення. Для вирішення цих проблем мають відбутися фундаментальні зміни у розвитку підготовки викладачів, розробці навчальних програм, навчальних матеріалів та оцінювання.

Компоненти та функції SIOP демонструють ряд аспектів, які роблять діяльність викладача ефективною. Модель SIOP об'єднує особливості ефективного навчання в одне ціле, інтегрує іноземну мову з навчанням професійної діяльності, а в контексті сучасної української освіти це особливо актуально при переході до системи підготовки професійно-мобільних фахівців.

\section{Список літератури:}

1. Амирова Л. А. Развитие профессиональной мобильности педагога в системе дополнительного образования : автореф. дис. ... доктора пед. наук : 13.00.08. Уфа, 2009. $44 \mathrm{c}$.

2. Верещагин Е. М., Костомаров В. Г. Язык и культура. Москва, 1993. 246 с.

3. Вятютнев М. Н. Коммуникативная направленность обучения русскому языку в зарубежных школах. Русский язык за рубежом. 1977. № 6.38 с.

4. Пассов Е. И. Коммуникативный метод обучения иностранному говорению. Москва : Просвещение, 1985. 208 с.

5. Пашковская И. Н. Социально-педагогические основы профессионального самоопределения педагога : дис. ... д-ра пед. наук : 13.00.01. СанктПетербург, 2002. 345 с.

6. Сластенин В. А., Каширин В. П. Психология и педагогика : учеб. пос. Москва : Академия, 2001. 480 с.

7. Ступина С. Б. Технологии интерактивного обучения в высшей школе : Учебно-методическое пособие. Саратов : Издательский центр «Наука», 2009. 52 с.

8. Сушенцева Л. Л. Формування професійної мобільності майбутніх кваліфікованих робітників у професійно-технічних закладах: теорія і практика : монографія / за ред. Н. Г. Ничкало. Інститут професійно-технічної освіти НАПН України. Кривий Ріг : Видавничий дім, 2011. 439 с. 
9. Тер-Минасова С. Г. Язык и межкультурная коммуникация. Москва, 2000. $624 \mathrm{c}$.

10. Язловецька О. Соціалізація та виховання студентської молоді у ВНЗ. Наукові записки. Наукові записки [Кіровоградського державного педагогічного університету імені Володимира Винниченка]. Сер. : Педагогічні науки. 2012. Вип. 107(2). С. 260-270.

11. Boiron M. Apprendre et enseigner. Le français dans le monde, 1997. 290 p.

12. Wendy F. (2002). Book review of Making Content Comprehensible for English Language Learners: The SIOP Model by Jane Echevarria. Journal of Education for Students Placed at Risk (JESPAR). Vol. 7. Issue 1. P. 16-17.

\section{References:}

1. Amirova L. A. (2009) Razvitie professionalnoy mobilnosti pedagoga $v$ sisteme dopolnitelnogo obrazovaniya [The Development of professional mobility of a teacher in the system of additional education] (PhD Thesis), Ufa.

2. Vereshchagin E. M., Kostomarov V. G. (1993) Yazyk i kul'tura [Language and culture]. Moscow. (in Russian)

3. Vyatyutnev M. N. (1977) Kommunikativnaya napravlennost' obucheniyarusskomu yazyku v zarubezhnyh shkolah [Communicative orientation of teaching Russian in foreign schools]. Russkiy yazyk za rubezhom, no. 6, p. 38. (in Russian)

4. Passov E. I. (1985) Kommunikativnyy metod obucheniya inostrannomu govoreniyu [Communicative method of teaching foreign speech]. Moscow: Prosveshchenie. (in Russian)

5. Pashkovskaya I. N. (2002) Sotsial'no-pedagogicheskie osnovy professional'nogo samoopredeleniya pedagoga [Socio-pedagogical foundations of professional self-determination of a teacher] (PhD Thesis), St. Petersburg. (in Russian)

6. Slastenin V. A., Kashirin V. P. (2001) Psikhologiya i pedagogika [Psychology and pedagogy]. Moscow: Akademiya. (in Russian)

7. Stupina S. B. (2009) Tekhnologii interaktivnogo obucheniya v vysshey shkole [Interactive learning technologies in higher education]. Saratov: Izdatel'skiy tsentr «Nauka». (in Russian)

8. Sushenceva L. L. (2011) Formuvannia profesiinoi mobilnosti maibutnikh kvalifikovanykh robitnykiv u profesiino-tekhnichnykh zakladakh: teoriia i praktyka [Formation of professional mobility of future skilled workers in vocational schools: theory and practice]. Kryvyj Rig: Vydavnychyj dim. (in Ukrainian)

9. Ter-Minasova S. G. (2000) Yazyk i mezhkul'turnaya kommunikaciya [Language and intercultural communication]. Moscow. (In Russian)

10. Jazlovecjka O. (2012) Socialization and education of student youth in higher education institution. Pedaghoghichni nauky, 107(2), 260-270. (in Ukrainian)

11. Boiron M. Apprendre et enseigner. Le français dans le monde, 1997. 290.

12. Wendy F. (2002) Book review of Making Content Comprehensible for English Language Learners: The SIOP Model by Jane Echevarria. Journal of Education for Students Placed at Risk (JESPAR), vol. 7, issue 1, pp. 16-17. 